\title{
Nesting biology of the trap-nesting Neotropical wasp Trypoxylon (Trypargilum) aurifrons Shuckard (Hymenoptera, Crabronidae)
}

\author{
Mariana Marchi Santoni ${ }^{1,2} \&$ Marco Antonio Del Lama ${ }^{1,3}$
}

\begin{abstract}
${ }^{1}$ Laboratório de Genética Evolutiva de Himenópteros, Departamento de Genética e Evolução, Universidade Federal de São Carlos, Rodovia Washington Luis Km 235 - 13565.905, São Carlos-SP, Brasil.

${ }^{2}$ mmsantoni@gmail.com

${ }^{3} \mathrm{dmdl} @$ power.ufscar.br
\end{abstract}

\begin{abstract}
Nesting biology of the trap-nesting Neotropical wasp Trypoxylon (Trypargilum) aurifrons Shuckard (Hymenoptera, Crabronidae). The present study was carried out in three localities of the state of São Paulo, Brazil: Araras (Dec/03-Dec/06), São Carlos (Nov/04-Nov/06) and Rifaina (Jul/04-Dec/06). Trap-nests were distributed among sites in the sampling areas and were collected every 35 days. Data from 295 nests indicate that T. aurifrons is a multivoltine species, with higher rates of nest building and cell production in the warm, rainy season. The trap-nests used by the females ranged from 117 to $467 \mathrm{~mm}$ in length and 3.1 to $16.6 \mathrm{~mm}$ in diameter. All nests showed deep plugs and a vestibular cell was found in $37 \%$ of the complete nests. The number of cells per nest ranged from one to 12 . Females were larger than males, emerged from longer cells and their cocoons were significantly larger. A secondary 1:1 sex ratio was found in Araras and Rifaina. No correlation was observed between the diameter of the trap-nest and sex ratio. Males were usually oviposited in the first brood cells. Male and female developmental time from egg to adult was longer in the cold, dry season. Trypoxylon aurifrons provisioned their nests mainly with orb-spiders from the family Araneidae. The most important mortality factor was the death of immature forms, probably due to development failure. The most important parasitoid was Melittobia sp.
\end{abstract}

KEYWORDS. Nest architecture; parasitoid; prey; sex ratio; seasonality.

\begin{abstract}
RESUMO. Biologia da nidificação de Trypoxylon (Trypargilum) aurifrons Shuckard (Hymenoptera, Crabronidae) em ninhos-armadilhas. Este estudo foi realizado em três localidades do estado de São Paulo: Araras (dez/03-dez/06), São Carlos (nov/04-nov/06) e Rifaina (jul/04-dez/06). Ninhos-armadilhas foram distribuídos em diferentes sítios das áreas amostradas e coletados a cada 35 dias. Dados de 295 ninhos mostraram que T. aurifrons é uma espécie multivoltina, com maiores taxas de nidificação e produção de células na estação quente e chuvosa. Os ninhos-armadilhas utilizados pelas fêmeas variaram de 117 a $467 \mathrm{~mm}$ de comprimento e de 3,1 a $16,6 \mathrm{~mm}$ de diâmetro. Todos os ninhos apresentaram parede de fundo e célula vestibular foi constatada em $37 \%$ dos ninhos completos. O número de células por ninho variou de um a 12. Fêmeas emergiram de células e pupários maiores, sendo significantemente maiores que os machos. Razão sexual secundária igual a 1:1 foi observada em Araras e Rifaina. Não foi encontrada correlação significativa entre a razão sexual e o diâmetro do tubo. Machos foram encontrados principalmente nas primeiras células de cria. O tempo de desenvolvimento ovo-adulto foi mais longo na estação fria e seca. Trypoxylon aurifrons aprovisionou seus ninhos principalmente com aranhas da família Araneidae. O principal fator de mortalidade foi a interrupção do desenvolvimento das formas imaturas e o parasitóide mais freqüentemente encontrado foi Melittobia sp.
\end{abstract}

PALAVRAS-CHAVE. Arquitetura intranidal; parasitóide; presas; razão sexual; sazonalidade.

Among the Crabronidae, the genus Trypoxylon Latreille encompasses nearly 660 species of cosmopolitan solitary wasps (Hanson \& Menke 1995). These insects are considered excellent model-organisms to test theories on parental care (Brockmann 1992; Brockmann \& Grafen 1989; Coville \& Coville 1980), parental investment (Molumby 1997), sex allocation (Oku \& Nishida 1999, 2001) and sex ratio (Brockmann \& Grafen 1992).

Based on differences in behavior and morphology, Richards (1934) divided this group into two subgenera: Trypoxylon and Trypargilum. The latter is restricted to the New World (Bohart \& Menke 1976) and includes about 100 species, 64 of which are restricted to South America (Amarante 2002).

Trypoxylon (Trypargilum) comprises a group of solitary wasps. Each female constructs her nest and provisions it with spiders. Some species nest in preexisting tubular cavities and divide them into a linear series of cells with mud partitions. Unlike most solitary wasps, $T$. (Trypargilum) males mate with females when the nest is founded and remain inside until its completion (Coville 1982).

Aspects of the natural history of $T$. (Trypargilum) species, such as nest architecture, nest-building time, sex ratio, parental investment, parasites and parasitoids have been described for Trypoxylon lactitarse Saussure 1867 (Camillo et al. 1993; Camillo \& Brescovit 1999; Buschini et al. 2006), T. rogenhoferi Kohl 1884 (Camillo et al. 1994; Garcia \& Adis 1995; Peruquetti \& Del Lama 2003), T. monteverdeae Coville 1982 (Brockmann 1992), T. aestivale Richards 1934 (Camillo 1999), T. antropovi Coville 1985 (Camillo 1999) and T. opacum (Buschini \& Wolff 2006). However, data on the biology of tropical species is scarce in comparison to temperate species.

Trypoxylon (Trypargilum) aurifrons Shuckard is a 
Neotropical species restricted to Venezuela, Colombia, the Guyanas, Paraguay and Brazil (Amarante 2002). According to Coville's (1982) classification, this species is included in the nitidum group, which contains most of the species from the subgenus. Information on the morphology and taxonomy of T. aurifrons can be found in Richards (1934) and Bohart \& Menke (1976). However, there is no data on the nesting biology of this species in the literature.

This paper reports aspects of the nesting biology of Trypoxylon aurifrons in trap-nests. Our results will allow comparative studies with other Neotropical species from the subgenus and will also be useful for future studies on population genetics and the intranidal sociogenetic structure of T. aurifrons.

\section{MATERIALAND METHODS}

Study locality. Trypoxylon aurifrons nests were sampled in three localities of the state of São Paulo: the Universidade Federal de São Carlos (UFSCar) campus at Araras (22 $18^{\circ}$ 'S, $\left.47^{\circ} 22^{\prime} \mathrm{W}, 629 \mathrm{~m}\right)$, the UFSCar campus at São Carlos $\left(22^{\circ} 01^{\prime} \mathrm{S}\right.$, $\left.47^{\circ} 53^{\prime} \mathrm{W}, 850 \mathrm{~m}\right)$ and Fazenda Rio Branco at Rifaina $\left(20^{\circ} 04^{\prime} \mathrm{S}\right.$, $\left.47^{\circ} 25^{\prime} \mathrm{W}, 575 \mathrm{~m}\right)$. These localities are classified as having a Cwa climate (Koeppen system) characterized by two welldefined seasons: one warm and rainy (October-March), with high rainfall and temperatures above $22^{\circ} \mathrm{C}$; and the other cold and dry (April-September), with low precipitation and temperatures below $18^{\circ} \mathrm{C}$.

Sampling in Araras was from December 2003 to December 2006 at eight sites; sampling in São Carlos was from November 2004 to November 2006 at two sites, and sampling in Rifaina was from July 2004 to December 2006 at six sites. All sites were located in old buildings near a water source.

Thirty collections were made in Araras, 14 in São Carlos and 17 in Rifaina. The meteorological data from the period can be found on the UFSCar campus website (www.ufscar.br).

Sampling program. The trap-nests were made of dry bamboo stems sectioned below each node. Bamboo stems of various lengths (100 to $652 \mathrm{~mm}$ ) and inner diameters (3.0 to $20.0 \mathrm{~mm}$ ) were used. Bundles of 8-12 units with similar dimensions were placed horizontally in covered areas at different sites in the study areas. Care was taken to offer a similar number of trap-nests with various dimensions at each site. Approximately 1,000 trap-nests were monthly offered in Araras, 500 in Rifaina and 300 in São Carlos. The trap-nests were checked approximately every 35 days.

The trap-nests used by the wasps were replaced with new ones and transported to the Laboratório de Genética Evolutiva de Himenópteros (LGEH), where they were opened. If eggs and/or larvae were present, the nest was closed again until the cocoon stage was reached. Cocoons were individually placed in vials labeled with the numbers of the trap-nest and cell and kept at room temperature until the emergence of the adults, at which time the species were identified.

Data Collected. The length and diameter of all trap-nests used by $T$. aurifrons were measured and the number of cells was counted. Since nest construction was not monitored, each progeny was treated as independent data. Aspects of the intranidal architecture, such as closure and deep plugs, and the presence of parasitoids were registered. The emergence, sex and weight (precision to $\pm 1 \mathrm{mg}$ ) of the adults were recorded. To estimate body size, the forewing length (FWL) of some adults was measured along the edge of the wing from the tegula to the distal end. Direct observations were carried out in São Carlos from December 2005 to March 2006 to estimate the developmental time. This was also indirectly estimated by the average number of days between the collection date and the emergence of adults. Emergence time was estimated from the time interval between the first and last adult emerged from a given nest. Spider provisions were removed from larval brood cells and stored in alcohol $70 \%$ for later identification by a specialist.

Some T. aurifrons individuals were mounted on entomological pins and sent for identification in order to be used for the identification of new individuals. Specimens were deposited at the Museu de Zoologia da Universidade de São Paulo and at the LGEH.

Data analysis. Statistical analyses were carried out following procedures described by Zar (1999), using BioEstat 4.0 (Ayres et al. 2005) and considering a 5\% significance level. Mean $(\bar{X})$ and Standard Deviation $( \pm)$ were given whenever appropriate.

Length and diameter values of the trap-nests used by $T$. aurifrons females at the three areas were pooled. The number of cells per nest was estimated from nests with a closure plug (complete nests).

Pearson's correlation test was used (i) to determine association between the number of nests and total number of cells in relation to seasonal conditions (average daily temperature and total rainfall of the period) in Araras; (ii) to verify association between the number of cells and the number of nests produced in each period and the number of cells per nest with length of the trap-nest; and (iii) to determine association between male and female weight and FWL.

The Kruskal-Wallis non-parametric test was used to verify differences between the number of cells per nest in each sampling areas. The Mann-Whitney test was used to compare cell and cocoon dimensions of both sexes.

The average values of male and female weight and FWL were compared by the $t$ test. Analysis of Variance (ANOVA) with an a posteriori Tukey test was used to compare differences in adult body mass produced at each area over the two seasons. Male and female weight variation were tested for normality by the D'Agostino test. ANOVA was used to compare weight variance between nestmates from nests with at least two males or females to weight variance between individuals from different nests in these two sampling areas.

A $\chi^{2}$ test was used to determine whether the secondary sex ratio (based on emerged individuals) deviated from a 1:1 proportion. Parental investment was estimated from the number of males and females produced and the amount of resources spent on each sex (measured by weight). An $\chi^{2}$ test was used 
to compare mortality and parasitism rates as well as the protective role of the vestibular cell. The percentage of males from complete nests where all individuals had emerged was arc-sin transformed and correlated to trap-nest diameter through linear regression to determine whether tube diameter affects the intranidal sex ratio.

\section{RESULTS}

Nesting activity at different sites. A total of 2,431 nests of solitary bees and wasps were sampled in the three areas, $87 \%$ of which were founded by Trypoxylon (Trypargylum) wasps. A total of 295 nests of T. aurifrons were collected: 113 in Araras, 34 in São Carlos and 148 in Rifaina. In these areas, most of the nests were found at a single site (51\% in Araras, $85 \%$ in São Carlos and $43 \%$ in Rifaina).

Seasonal abundance. Although Trypoxylon aurifrons females constructed their nests throughout the year, most of the nests in Araras (88\%), São Carlos (71\%) and Rifaina (63\%) were collected in the warm, rainy season. As a more regular sampling effort was made in Araras, data from there were used to determine the association between number of nests and climate conditions (Fig. 1). The number of nests had a significant association to the average daily temperature of the period $(\mathrm{r}=0.47, \mathrm{P}=0.01, \mathrm{DF}=28)$, but not to rainfall $(\mathrm{r}=0.21$, $\mathrm{P}=0.26, \mathrm{DF}=28)$.

A total of 1,252 brood cells from $T$. aurifrons nests were sampled in Araras ( $\mathrm{n}=584)$, São Carlos $(\mathrm{n}=142)$ and Rifaina ( $=526)$. Most $(75 \%)$ were produced in the warm, rainy season (Fig. 1). As expected, the number of cells had a strong association to the number of nests produced in the period $(\mathrm{r}=$ $0.87, \mathrm{P}=0.00, \mathrm{DF}=59$ ). The number of cells in the nests from Araras was significantly correlated to the average daily temperature of the period $(\mathrm{r}=0.51, \mathrm{P}=0.00, \mathrm{DF}=28)$, but not to rainfall $(\mathrm{r}=0.16, \mathrm{P}=0.40, \mathrm{DF}=28)$.

Nest architecture. Trap-nests used by $T$. aurifrons had

Table I. Architecture of Trypoxylon aurifrons nests in trap-nests sampled in three localities of the state of São Paulo ( $\mathrm{N}$ = number of observations).

\begin{tabular}{lccc}
\hline \multicolumn{1}{c}{ Nest structure } & $\begin{array}{c}\text { Amplitude } \\
\text { of variation }\end{array}$ & $\bar{X}$ & $\mathrm{~N}$ \\
& & & \\
\hline $\begin{array}{l}\text { Number of cells per nest } \\
\text { (from Araras) }\end{array}$ & $1-12$ & $6 \pm 2$ & 94 \\
$\begin{array}{l}\text { Number of cells per nest } \\
\text { (from São Carlos) }\end{array}$ & $1-11$ & $5 \pm 2$ & 25 \\
Number of cells per nest & & & \\
(from Rifaina) & $1-12$ & $4 \pm 2$ & 90 \\
Thickness of cell partition (mm) & $1.3-2.7$ & $2.2 \pm 0.5$ & 25 \\
Thickness of closure plug (mm) & $1.9-3.3$ & $2.5 \pm 1.5$ & 9 \\
Length of nest (cm) & $4.9-21.2$ & $12.4 \pm 3.9$ & 28 \\
Length of the deep cell (cm) & $0,6-4.0$ & $1.2 \pm 0.9$ & 28 \\
Length of the vestibular cell (cm) & $1.0-6.5$ & $2.2 \pm 1.4$ & 35 \\
Length of the brood cell (cm) & $0.6-5.0$ & $1.8 \pm 0.7$ & 319 \\
Length of male brood cell (cm) & $0.7-3.3$ & $1.6 \pm 0.5$ & 92 \\
Length of female brood cell (cm) & $1.0-4.8$ & $1.9 \pm 0.7$ & 86 \\
\hline
\end{tabular}

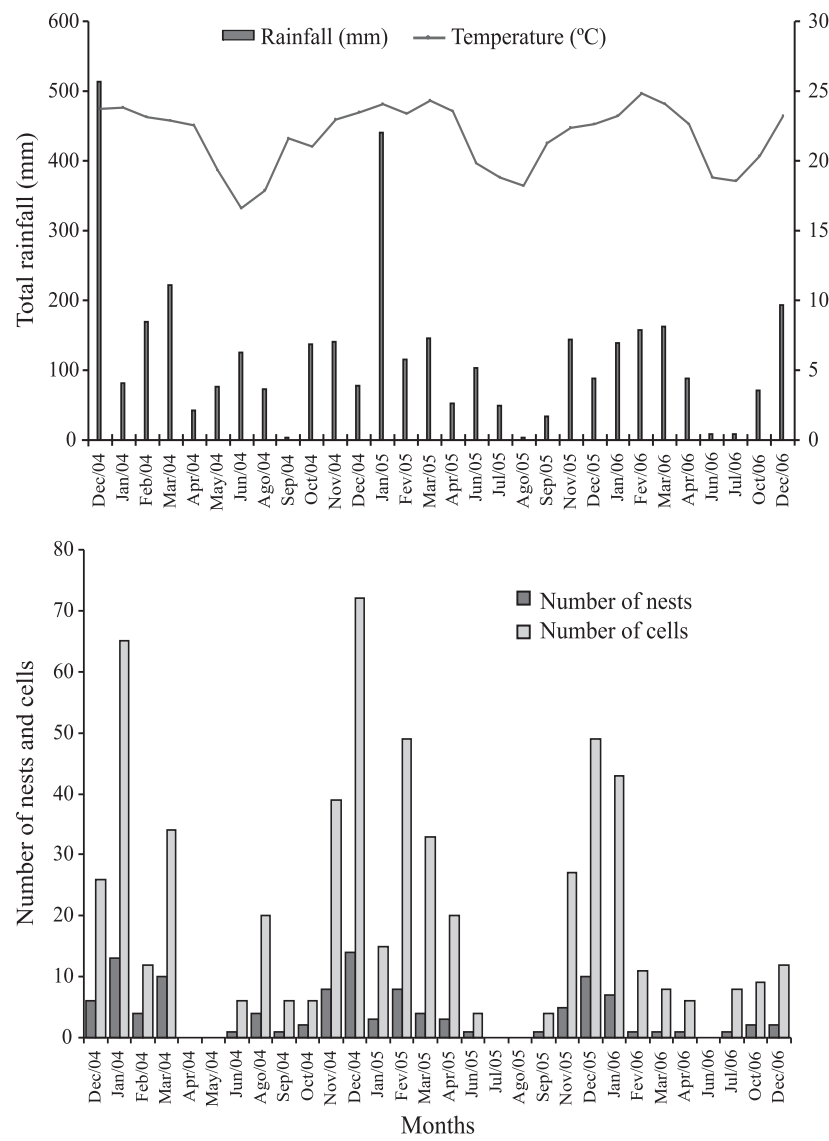

Figure 1. Climate conditions and number of Trypoxylon aurifrons nests and brood cells obtained monthly during three years of sampling in Araras (SP).

lengths ranging from 117 to $467 \mathrm{~mm}(\bar{X}=241.3 \pm 6.6, \mathrm{n}=295)$ as well as inner diameters between 3.1 and $16.6 \mathrm{~mm}(\bar{X}=6.7 \pm 1.7$, $\mathrm{n}=295)$. Most nests (88\%) were built in trap-nests with 150 to $349 \mathrm{~mm}$ in length (Fig. 2a) and 5.0 to $9.9 \mathrm{~mm}$ in diameter (Fig. 2b).

Complete nests had one to 12 brood cells. On average, five cells were found in each nest. The number of brood cells per nest was significantly lower in São Carlos than in Araras, but no difference was found in the number of cells per nest between Araras and Rifaina or between Rifaina and São Carlos (KruskalWallis: $\mathrm{H}_{\text {Araras } x \text { São Carlos }}=11.82, \mathrm{P}<0.05 ; \mathrm{H}_{\text {Araras } x \text { Rifaina }}=1.72$, P $\left.=0.19 ; \mathrm{H}_{\text {Rifaina X São Carlos }}^{\text {Araras }}=2.37, \mathrm{P}=0,07\right)($ Table 1$)$. No significant correlation was found between the number of cells per nest and the length of the trap-nest $(r=0.10, P=0.16, D F=207)$.

All T. aurifrons nests had similar architecture. The partition walls were rough and convex on the inner side, while smooth and concave on the outer side (Table I). A layer of mud before the first brood cell (deep plug) was found in all nests and a double deep plug was found in two nests $(0.8 \%)$. There was a deep cell (empty cell between the deep plug and first brood cell) in 28 nests (10\%). A total of 209 nests had a closure plug at the end of the tube (complete nests) and 26 nests had two closure plugs. In complete nests, $37 \%$ had a vestibular cell (an 
Table II. Dimensions of male and female cocoons (mm), weight-atemergence (WE) $(\mathrm{mg})$ and forewing length $(\mathrm{FWL})(\mathrm{mm})$ in Trypoxylon aurifrons $(\mathrm{N}=$ number of observations).

\begin{tabular}{lccc}
\hline & $\begin{array}{c}\text { Amplitude } \\
\text { of variation }\end{array}$ & $\bar{X}$ & $\mathrm{~N}$ \\
\hline Male cocoon length & $8-14$ & $11.5 \pm 1.3$ & 73 \\
Female cocoon length & $8-14$ & $10.6 \pm 1.2$ & 54 \\
Male WE & $14-42$ & $25.3 \pm 6.0$ & 255 \\
Female WE & $11-60$ & $32.9 \pm 7.8$ & 285 \\
Male WE - hot season & $14-42$ & $25.6 \pm 5.8$ & 211 \\
Female WE - hot season & $11-50$ & $33.9 \pm 7.3$ & 232 \\
Male WE - cold season & $14-28$ & $19.8 \pm 5.1$ & 44 \\
Female WE - cold season & $12-43$ & $27.4 \pm 7.8$ & 53 \\
Male FWL & $5.99-8.12$ & $7.24 \pm 0.50$ & 82 \\
Female FWL & $6.38-8.70$ & $7.74 \pm 0.44$ & 108 \\
\hline
\end{tabular}

empty space between the closure plug and the last provisioned cell). Brood cells had variable lengths (Table I). Male cells were significantly smaller than female cells in length (MannWhitney $=2.85, \mathrm{P}=0.00)$.

Cocoon. T. aurifrons cocoons were cylindrical, dark brown, somewhat shiny and smooth, with a round posterior end. Cocoons ranged from 7 to $14 \mathrm{~mm}$, with an average length of $11.2 \mathrm{~mm}( \pm 7 \mathrm{~mm} ; \mathrm{n}=209)$. The male cocoon was significantly shorter than female cocoon (Mann-Whitney $=1.21, \mathrm{P}=0.00$ ) (Table II).

Adults. T. aurifrons females were significantly heavier than males $(\mathrm{t}=12.31, \mathrm{P}=0.00)$ (Table II). A one-way ANOVA with an a posteriori Tukey test confirmed the difference between male and female weights, while also revealing weight differences between individuals of the same sex collected in Araras and Rifaina $\left(\mathrm{F}_{\text {male }}=4.95, \mathrm{P}<0.01 ; \mathrm{F}_{\text {female }}=4.81, \mathrm{P}<0.01\right.$, respectively $)$. Individuals produced in the warm season were significantly heavier from those produced in the cold season, regardless of sex or origin $(F=38.08, P=0.00)$ (Table II). Weight was normally distributed among T. aurifrons males and females from Araras and Rifaina (Table III). ANOVA showed lower weight variance between nestmates than between individuals from different nests (Table III).

Wings from 108 T. aurifrons females and 82 males were analyzed (Table II). The weight-at-emergence of T. aurifrons adults had a positive and highly significant correlation with FWL for both sexes $\left(r_{\text {males }}=0.72, \mathrm{P}=0.00, \mathrm{DF}=80 ; \mathrm{r}_{\text {females }}=\right.$ $0.68, \mathrm{P}=0.00 ; \mathrm{DF}=106)$. FWL differences between sexes were also significant $(\mathrm{t}=7.74, \mathrm{P}=0.00)$.

Developmental time. A developmental time from 26 to 31 days $(\bar{X}=28 \pm 1.5, \mathrm{n}=7$ ) was estimated directly. An indirect estimate through the nests from Araras (where a more regular sampling effort was made) gave an average of $22.8 \pm 7.2(\mathrm{n}=$ 97 males) and $22.3 \pm 7.3$ days $(n=125$ females $)$ in the warm season and $32.1 \pm 5.5(n=17$ males $)$ and $32.6 \pm 9.4$ days $(n=20$ females) in the cold season.

From 155 nests (52\%), all individuals emerged at the same day. In 209 nests (71\%), the interval between the first and last emergence was five days. This interval reached 21 days in the cold season.

Sex ratio and distribution. An overall 1:1 sex ratio was observed in Araras (114 males: 145 females; $\chi^{2}=3.59, \mathrm{P}=0.0623$, $\mathrm{DF}=1$ ) and Rifaina (169 males: 153 females; $\chi^{2}=0.795, \mathrm{P}=$ 0.4032, DF $=1$ ), but not in São Carlos (31 males:50 females; $\chi^{2}$ $=4,457, \mathrm{P}=0.0455, \mathrm{DF}=1)$. Females were $30 \%$ bigger than males. The parental investment was female-biased in all three areas: $62 \%$ in Araras, $60 \%$ in São Carlos and 57\% in Rifaina.

The sex ratio was not associated to diameter of the tube in nests where all brood emerged $\left(\mathrm{y}=-0.008 \mathrm{x}+0.6153 ; \mathrm{R}^{2}=\right.$ $0.0035 ; \mathrm{P}=0.72 ; \mathrm{DF}=37)$. However, a higher male production was found in trap-nests with diameters between 3 and $5 \mathrm{~mm}$ (Fig. 3). A nonrandom distribution of the sexes inside the nest was observed. Males were usually found in the first provisioned cells (Table IV). In complete nests where all adults emerged, a male $(n=12)$ and female $(n=3)$ single-sex progeny was found.

Prey. Spiders from 14 provisioned cells were collected from $T$. aurifrons nests in the rainy $(\mathrm{n}=143$ spiders $)$ and dry seasons ( $\mathrm{n}=8$ spiders). Of the 151 identified spider prey, $150(99 \%)$ belonged to the family Araneidae. Eight spiders were female, seven were male and 136 were immature (unidentified sex). The most common prey was Eustala $(\mathrm{n}=23)$, mainly represented by Eustala gr. fuscovittata $(\mathrm{n}=19)$. T. aurifrons also used Metazygia $\mathrm{sp}_{1}(\mathrm{n}=4)$, Argiope argentata $(\mathrm{n}=4)$, Araneus spp $(\mathrm{n}=4)$, Acacesia $\mathrm{sp}_{1}(\mathrm{n}=1)$ and Mecynogea $\mathrm{sp}_{1}$ $(\mathrm{n}=1)$. Only one immature specimen from the genus Leucage (Tetragnatidae) was sampled, which occurred in São Carlos on February 25, 2005.

In Araras ( $\mathrm{n}=6$ cells), $81 \%$ of the spiders were from the genus Eustala and 19\% were from the genus Araneus and Metazygia. In São Carlos ( $\mathrm{n}=3$ cells), the most common genera were Argiope ( $100 \%)$. In Rifaina ( $\mathrm{n}=5$ cells), the genera Argiope and Araneus each represented $38 \%$ of the captured spiders, while the genera Acacesia and Mecynogea each constituted $12 \%$ of the prey.

Mortality and natural enemies. A total of 1,252 brood cells were sampled. Development to adulthood occurred in $53 \%$ of cells (Table V). Death of immature forms was observed in 590 cells in the egg (12\%), larval (2\%) and pupal (86\%) stages. Mortality and parasitism rates were significantly different in the three areas $\left(\chi^{2}=10.52, \mathrm{P}=0.00, \mathrm{DF}=2 ; \chi^{2}=15.28, \mathrm{P}=0.00\right.$, $\mathrm{DF}=2$, respectively), with the highest rates in Araras (Table $\mathrm{V})$.

Table III. Normality test (D) for male and female weight values and ANOVA test $(\mathrm{F})$ for weight variance between nestmates and between individuals from different nests in Araras and Rifaina - SP.

\begin{tabular}{cccccc}
\hline Test & \multicolumn{2}{c}{ D'Agostino $^{\prime}$ A } & \multicolumn{3}{c}{ ANOVA } \\
\hline Araras & $\mathrm{D}$ & $\mathrm{P}$ & $F$ & $\mathrm{DF}$ & $\mathrm{P}$ \\
\hline Male & 0.2824 & $>0.05$ & 3.09 & 32 & 0.001 \\
Female & 0.2800 & $>0.05$ & 3.26 & 46 & 0.000 \\
Rifaina & & & & & \\
\hline Male & 0.2827 & $>0.05$ & 1.84 & 31 & 0.045 \\
Female & 0.2803 & $>0.05$ & 4.28 & 28 & 0.000 \\
\hline
\end{tabular}




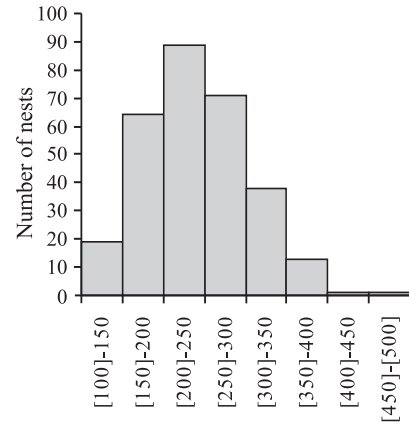

a) Lenght ( $\mathrm{mm})$

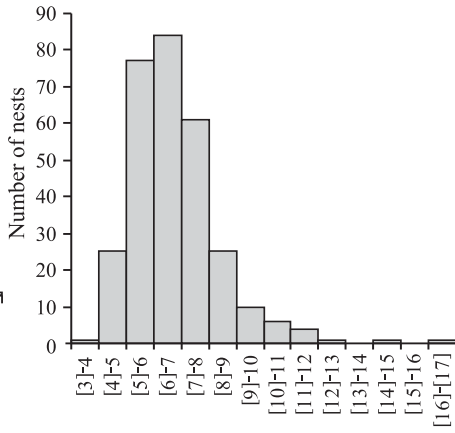

b) Diameter (mm)
Figure 2. Lengths (a) and diameters (b) of the trap-nests used by Trypoxylon aurifrons.

Parasitoids caused the death of 209 brood cells (17\%). Melittobia sp. (Hymenoptera: Eulophidae) was the most common parasitoid of the T. aurifrons nests and was found in 324 cells (26\%). During the three years of sampling in Araras, the higher presence of the parasitoid was positively associated to the number of hosts.

Adults from the families Chrysididae, Ichneumonidae and Chalcididae were found in six, two and one nests, respectively. These parasitoids were observed mainly in the last brood cell ( 6 of the 9 nests) and were found in nests with ( 3 in 77 nests) or without (6 in 132 nests) a vestibular cell $\left(\chi_{\text {ind }}^{2}=0.05, \mathrm{P}=\right.$ $0.89, \mathrm{DF}=1)$.

\section{DISCUSSION}

Conditions and resources for nest building. A number of factors affect nest-building rates among Hymenoptera, such as temperature, wind and rainfall, as well as the availability and features of natural cavities (Morato \& Martins 2006). Our results indicate that temperature is the main seasonal condition affecting T. aurifrons nesting behavior. Similar to other Neotropical wasp species, such as T. rogenhoferi (Camillo et al. 1994; Camillo \& Brescovit 1999), T. lactitarse (Camillo \& Brescovit 1999; Camillo et al. 1993; Buschini et al. 2006) and T. opacum (Buschini \& Wolff 2006), T. aurifrons nesting activity was greater during the warm season.

The size and quality of the brood were also affected by the season. Most cells were produced in the warm season. Larger individuals were found in this season as well, regardless of sex. Brockmann \& Grafen (1992) observed a seasonal pattern of sex allocation in T. politum due to temperature differences. Temperature also affects development time, which was shorter in the warm season. The development time seen in the three areas suggests that $T$. aurifrons has a development cycle with no diapause. Our results demonstrate that $T$. aurifrons is a multivoltine species, like T. rogenhoferi (Camillo et al. 1994; Camillo \& Brescovit 1999), strengthening Coville's (1982) suggestion that Trypoxylon species are bivoltine or multivoltine in tropical and subtropical regions.

Coville (1982) reports that the number of trap-nests available may affect the nest choice of Trypoxylon females. Moreover, Trypoxylon species require a minimum cavity diameter, which is determined by the body size of the founding female and prey size (Garcia \& Adis 1995). The maximum diameter is determined by preventive action against attacks from parasitoids and predators, as greater diameters result in thinner plugs (Coville \& Coville 1980).

Trypargilum species differ in the number of families of spider preyed and in the percentage of each spider family among the prey (Coville 1982). T. rogenhoferi prefers Alpaida spiders (Camillo et al. 1994; Camillo \& Brescovit 1999, 2000; Garcia \& Adis 1995); T. lactitarse mainly collects Alpaida and Eustala (Camillo et al. 1993; Camillo \& Brescovit 1999; Buschini et al. 2006); T. antropovi uses spiders from the genus Eriophora (Camillo 1999); T. tenoctitlan collects Metazygia (Coville \& Coville 1980); and T. opacum collects Bertrana and Eustala (Buschini \& Wolf 2006).

Although the handling of the cocoons may have produced a biased estimate of the mortality rate, the main mortality factor in T. aurifrons was the death of the immature forms, which is a result similar to that found for other species of Trypoxylon that use trap-nests (Camillo et al. 1993; Camillo et al. 1994; Camillo \& Brescovit 1999; Garcia \& Adis 1995). Parasitoidism of T. aurifrons nests resulted in $16 \%$ of the deaths. The parasitized cells were generally found in the last cells, as observed by Coville (1982) and Jayasingh \& Taffe (1992) in species from this genus.

Melittobia sp., which is the main parasitoid of T. aurifrons, was found in 324 cells $(25.9 \%)$, but only caused the death of 205 individuals $(16.4 \%)$, usually in the egg stage. This parasitoid was also found in T. antropovi (Camillo 1999), $T$. rogenhoferi (Camillo et al. 1994), T. politum (Molumby 1995), T. lactitarse (Camillo et al. 1993) and T. antropovi (Camillo 1999) nests. Adult Ichneumonidae, Chalcididae and Chrysididae were found in T. aurifrons, T. rogenhoferi (Camillo et al. 1994), T. lactitarse (Camillo et al. 1993), T. tenoctitlan

Table IV. Percentage of emerged Trypoxylon aurifrons males in each cell* according to their position in the nests $(-=$ no emergences).

\begin{tabular}{|c|c|c|c|c|c|c|c|c|c|c|c|c|c|}
\hline $\begin{array}{l}N^{\circ} \text { cells } \\
\text { per nest }\end{array}$ & $\begin{array}{l}\mathrm{N}^{\circ} \text { of } \\
\text { nests }\end{array}$ & 1 & 2 & 3 & 4 & 5 & 6 & 7 & 8 & 9 & 10 & 11 & 12 \\
\hline 1 & 17 & 75 & & & & & & & & & & & \\
\hline 2 & 16 & 78 & 55 & & & & & & & & & & \\
\hline 3 & 32 & 50 & 50 & 56 & & & & & & & & & \\
\hline 4 & 38 & 56 & 71 & 21 & 35 & & & & & & & & \\
\hline 5 & 35 & 82 & 59 & 50 & 43 & 53 & & & & & & & \\
\hline 6 & 32 & 62 & 50 & 48 & 45 & 50 & 33 & & & & & & \\
\hline 7 & 23 & 60 & 50 & 60 & 50 & 10 & 45 & 45 & & & & & \\
\hline 8 & 19 & 75 & 75 & 43 & 0 & 14 & 43 & 80 & 100 & & & & \\
\hline 9 & 9 & 100 & 50 & 50 & 67 & 50 & 100 & 25 & 67 & 75 & & & \\
\hline 10 & 7 & 3 & - & 0 & 0 & 0 & 0 & 50 & 0 & 0 & 50 & - & \\
\hline 11 & 3 & 3 & - & 100 & 100 & 100 & 100 & 0 & 50 & 0 & 0 & 0 & 0 \\
\hline 12 & 2 & 1 & - & - & - & - & - & 0 & 100 & 0 & - & - & 0 \\
\hline Total & 233 & 66 & 54 & 45 & 43 & 37 & 45 & 55 & 73 & 55 & 50 & 0 & 0 \\
\hline
\end{tabular}

* Cells are numbered from inner end of nest toward the entrance. 


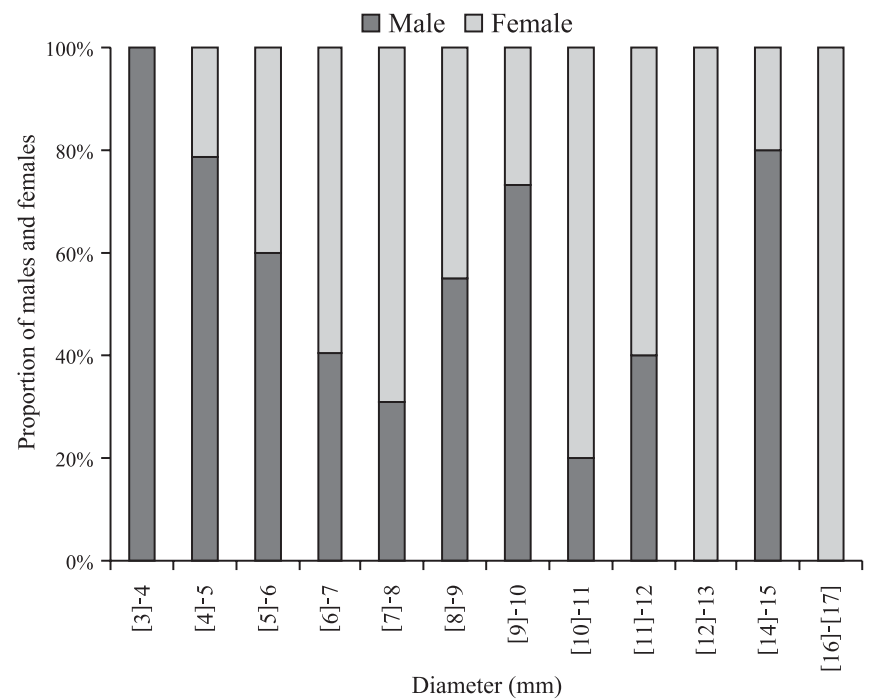

Figure 3. Proportion of T. aurifrons males and females according to the inner diameter of the trap-nest.

(Coville \& Coville 1980) and T. antropovi (Camillo 1999) nests.

Site distribution of the nests. Trypoxylon aurifrons nesting behavior seems to be site preferential in the three sampling areas. T. rogenhoferi, T. lactitarse and T. nitidum exhibit similar behavior in the three sampling areas (Santoni \& Del Lama, in preparation). Is it possible that resources have affected this "habitat partition" exhibited by T. aurifrons?

We disposed a large number of trap-nests with different inner diameter sizes at each nesting site. Thus, there was no lack of substrate or nest construction material that would explain why T. aurifrons preferentially nests at one site, while other Trypoxylon species preferentially nest at other sites.

Our study confirms previous data on the foraging preference of Trypoxylon (Trypargilum) for the Araneidae family and also suggests an absence of interspecific competition for prey among Trypargilum species. This species-specific prey preference may be an adaptive response to prevent overlapping in the prey collected (Camillo \& Brescovit 1999). If the habitat partition exhibited by Trypoxylon species could not be easily explained by interspecific competition, an independent evolution of cognitive abilities to recognize important habitat features ('clues', as proposed by Storch \& Frynta, 2000) may be an alternative explanation. As the parasitoids found in T. aurifrons nests are similar to those of other Trypargilum nests, we suggest that the presence of shared natural enemies may be a clue to why one species avoids a site used by another species.

This habitat partition would be reinforced by the presence of the first females as a sign of a safe place for nesting. Phylopatry is an important factor in nest-building site selection in changing habitats (Potts \& Willmer 1997) and may be another factor in this behavior. Moreover, the reuse of the parental nest is relatively common among solitary hymenopterans that form aggregations (Roubik 1989). There are no studies on phylopatric behavior in Trypoxylon species. Mark-and- recapture studies or molecular genetic analyses are required to confirm such behavior.

Intranidal structure. Trypoxylon aurifrons nests exhibited features similar to those described for species of the subgenus Trypargilum that nest in preexisting cavities (Coville 1982; Coville \& Coville 1980; Garcia \& Adis 1995; Camillo et al. 1993; Camillo et al. 1994; Genaro 1996a, 1996b). The presence of a deep plug has been described for other Trypoxylon species (Coville \& Coville 1980; Garcia \& Adis 1995; Camillo et al. 1994; Camillo et al. 1993; Genaro 1996a, 1996b). Based on the nesting biology of T. rogenhoferi, Garcia \& Adis (1995) suggest that this behavior is restricted to species whose larvae use mud to make cocoons, as occurs with $T$. aurifrons, since this plug is destined to the first cell built. Vestibular cells were also found in nests of other Trypargilum species that nest in preexisting cavities. However, as proposed by Coville (1982), this structure did not represent a barrier for the parasitoids in Trypoxylon aurifrons (present data) and T. rogenhoferi nests (Garcia \& Adis 1995).

T. aurifrons cocoons had the features described by Coville (1982) for the nitidum complex cocoon, where the anterior end is truncate, with a prominent nipple. According to Coville (1979), cocoon features are an adequate tool for grouping species: species from the subgenus Trypoxylon present fragile cocoons, whereas species from the subgenus Trypargilum have hard cocoons, as they incorporate mud in this structure (Garcia \& Adis 1995; Krombein 1967). In the present study, the sexes had different cocoon lengths, as in T. lactitarse (Camilo et al.1993; Buschini et al. 2006), where female cocoons are significantly larger than male cocoons. Similar male and female cocoon lengths were found in T. rogenhoferi (Camillo et al. 1994), T. opacum (Buschini \& Wolff 2006) and T. tenoctitlan (Coville \& Coville 1980) as well.

Adults. As weight-at-emergence was significantly correlated to FWL, it may be a good estimator for body size in T. aurifrons. FWL adequately estimates Trypoxylon body size as a consequence of the amount of food the brood receives (Coville \& Griswold 1983). Trypoxylon aurifrons females emerged from longer cells than males, which is similar to $T$. lactitarse (Buschini et al. 2006; Camillo et al .1993) and T. tenoctitlan (Coville \& Coville 1980), but different from $T$. rogenhoferi (Camillo et al. 1994, Garcia \& Adis 1995). ANOVA analysis demonstrated that nestmates have more similar

Table V. Number of cells, emerged and dead Trypoxylon aurifrons individuals collected in three areas of the state of São Paulo.

\begin{tabular}{rccc}
\hline & Araras & São Carlos & Rifaina \\
Cells & 584 & 142 & 526 \\
Emerged & $259(44 \%)$ & $81(57 \%)$ & $322(61 \%)$ \\
Deaths by parasitoids & $128(22 \%)$ & $17(12 \%)$ & $64(12 \%)$ \\
Melittobia sp. & 125 & 15 & 56 \\
Ichneumonidae & 1 & & 1 \\
Chrysididae & 2 & 2 & 6 \\
Chalcididae & & & 1 \\
By unknown causes & $197(34 \%)$ & $44(31 \%)$ & $140(27 \%)$ \\
\hline
\end{tabular}


weight-at-emergence than individuals from different nests, suggesting that a genetic factor affects this trait.

Trypoxylon aurifrons allocates more resources to produce larger females, as measured by FWL and weight-at-emergence. Dimorphism for body size is common among solitary hymenopterans. It is a well-registered fact that females are significantly larger than males in Trypoxylon species, including T. lactitarse (Camillo \& Brescovit 1999; Camillo et al. 1993; Buschini et al. 2006), T. rogenhoferi (Camillo \& Brescovit 1999), T. antropovi, T. aestivale (Camillo 1999) and T. politum (Brockmann \& Grafen 1992; Molumby 1997).

The reproductive success of bees and wasps that supply trophic resources to their brood depends on the maternal phenotype and the choices made by the mother upon laying its eggs (Peruquetti \& Del Lama 2003). Females provision their brood, affecting its size and resulting in the differences observed in some species of Crabronidae (Brockmann \& Grafen 1992; Molumby 1997; Peruquetti \& Del Lama 2003). Thus, the higher allocation of resources to one sex may be a way to maximize fitness.

A number of factors influence the intranidal sex ratio in Hymenoptera, as seen in Trypoxylon malaisei Gussakovskij 1933 (Oku \& Nishida 1999). Peruquetti \& Del Lama (2003) demonstrated that male-biased offspring can arise when trapnests with smaller diameters are used for nest building. However, this was not observed in T. aurifrons and Trypoxylon malaisei (Oku \& Nishida 1999).

Although the sex ratio was not different from 1:1 in Araras and Rifaina, the investment sex ratio was significantly femalebiased in the three areas. According to Rosenheim et al. (1996), if availability of provisioning resources increases and females become more egg-limited, they may choose one of two strategies: (i) they could increase provision masses per offspring and produce a less male-biased brood; or (ii) they could maintain an equal numerical sex ratio and a more femalebiased investment sex ratio. In Trypoxylon, sex distribution within the trap-nests is usually nonrandom. In some species, males are found in the first cells and females in the last cells, whereas an inverse arrangement of males and females is found among other species. Studies with Trypargilum species (Coville \& Coville 1980; Camillo et al. 1993; Camillo et al. 1994) have demonstrated that males are found in the first cells, as verified herein for T. aurifrons.

As 1:1 secondary sex ratio was found, a similar number of nests would be expected with a male or female single-sex progeny. The higher number of male single-sex progeny (13 to 2) suggests nest building by constrained (sperm-depleted or unmated) females. However, males and females from this subgenus mate immediately before or soon after the initial activities of nest construction (Coville 1982). Moreover, we observed the presence of male guards inside all nests built. This finding may alternatively be interpreted as a strategy for optimal sex allocation.

Our findings demonstrate that temperature was the environmental factor that most strongly affected $T$. aurifrons nesting biology and population dynamics. Many intranidal architecture features appeared to be similar to those described for other Neotropical species from this subgenus. These data will support analyses on the intranidal sociogenetic structure of Trypoxylon aurifrons and tests on the evolutionary role of the male guarding behavior found only in Trypargilum species. The phylopatric behavior and the occurrence of nest building by unfertilized females require further confirmation through molecular genetic analysis.

Acknowledgements. We are grateful to Dr. Adhemar Rodrigues Alves, owner of the Fazenda Rio Branco (Rifaina, SP). We thank Servio Tulio Pires Amarante for wasp species identification and Antonio Carlos Brescovit for spider species identification. We are also grateful to Rogério Oliveira Souza for helping in the nest sampling and FAPESP for financial support.

\section{REFERENCES}

Amarante, S. T. P. 2002. A synonymic catalog of the Neotropical Crabronidae and Sphecidae (Hymenoptera:Apoidea). Arquivos de Zoologia 37: 1-139.

Ayres, M.; M. Ayres Jr; D. L. Ayres \& A. S. Santos. 2005. BioEstat 4.0: aplicações estatísticas nas áreas das ciências biológicas e médicas. Belém, Sociedade Civil Mamirauá, 290p.

Bohart, R. M. \& A. S. Menke. 1976. Sphecidae wasps of the world. A generic revision. Berkeley, University of California Press, $695 \mathrm{p}$.

Brockmann, H. J. 1992. Male behavior, courtship and nesting in Trypoxylon (Trypargilum) monteverdeae (Hymenoptera: Sphecidae). Journal of the Kansas Entomological Society 65 : 66-84.

Brockmann, H. J. \& A. Grafen. 1989. Mate conflict and male behaviour in a solitary wasp, Trypoxylon (Trypargilum) politum (Hymenoptera: Sphecidae). Animal Behavior 37: 232-255.

Brockmann, H. J. \& A. Grafen. 1992. Sex ratios and life-history patterns of a solitary wasp, Trypoxylon (Trypargilum) politum (Hymenoptera: Sphecidae). Behavioral Ecology and Sociobiology 30: 7-27.

Buschini, M. L. T.; L. W. Lazzarini \& F. Niesing. 2006. Nesting biology of Trypoxylon (Trypargilum) lactitarse (Hymenoptera; Crabronidae) in trap-nests in southern Brazil. Brazilian Journal of Biology 66: $161-171$.

Buschini, M. L. T. \& L. W. Lazzarini. 2006. Notes on the biology of Trypoxylon (Trypargilum) opacum Brèthes (Hymenoptera; Crabronidae) in southern Brazil. Brazilian Journal of Biology 66: 915-926.

Camillo, E. 1999. Bionomics of Trypoxylon (Trypargilum) antropovi and Trypoxylon (Trypargilum) aestivale (Hymenoptera: Sphecidae). Iheringia 87: 29-36.

Camillo, E. \& A. D. Brescovit. 1999. Aspectos biológicos de Trypoxylon (Trypargilum) lactitarse Saussure e Trypoxylon (Trypargilum) rogenhoferi Kohl (Hymenoptera: Sphecidae) em ninhos-armadilha, com especial referência a suas presas. Anais da Sociedade Entomológica do Brasil 28: 251-262.

Camillo, E. \& A. D. Brescovit. 2000. Spider prey (Araneae) of Trypoxylon (Trypargilum) rogenhoferi (Hymenoptera: Sphecidae) in southeastern Brazil. Revista de Biologia Tropical 48: 647656.

Camillo, E.; C. A. Garófalo; G. Muccillo \& J. C. Serrano. 1993. Biological observation on Trypoxylon (Trypargilum) lactitarse Saussure in Southeastern Brazil (Hymenoptera, Sphecidae). Revista Brasileira de Entomologia 37: 769-778.

Camillo, E.; C. A. Garófalo \& J. C. Serrano. 1994. Observações sobre a biologia de Trypoxylon (Trypargilum) rogenhoferi Kohl (Hymenoptera: Sphecidae). Anais da Sociedade Entomológica do Brasil 23: 299-310.

Coville, R. E. 1979. Biological observations on Trypoxylon (Trypargilum) 
orizabense Richards in Arizona (Hymenoptera: Sphecidae). Journal of the Kansas Entomological Society 52: 613-620.

Coville, R. E. 1982. Wasps of the genus Trypoxylon subgenus Trypargilum in North America. Berkeley, University of California Press, 147 p.

Coville, R. E. \& P. L. Coville. 1980. Nesting biology and male behavior of Trypoxylon (Trypargilum) tenoctitlan in Costa Rica (Hymenoptera: Sphecidae). Annals of the Entomological Society of America 73: 110-119

Coville, R. E. \& C. Griswold. 1983. Nesting biology of Trypoxylon xanthandrum in Costa Rica with observation on its spider prey (Hymenoptera: Sphecidae; Araneae: Senoculidae). Journal of the Kansas Entomological Society 56: 205-216.

Garcia, M. V. B. \& J. Adis. 1995. Comportamento de nidificação de Trypoxylon (Trypargilum) rogenhoferi Kohl (Hymenoptera, Sphecidae) em uma floresta inundável de várzea na Amazônia Central. Amazoniana 13: 259-282.

Genaro, J. A. 1996a. Sobre la nidificación de Sceliphron caementarium y primer registro de Trypoxylon texense para Puerto Rico. Caribbean Journal of Science 32: 243-244.

Genaro, J. A. 1996b. Estructura del nido y capullo de Trypoxylon (Trypargilum) subimpressum (Hymenoptera: Sphecidae). Caribbean Journal of Science 32: 240-243.

Hanson, P. E. \& A. S. Menke. 1995. The Sphecid Wasps (Sphecidae), p. 621-649. In: P. E. Hanson \& I. A. Gauld (eds.). The Hymenoptera of Costa Rica. New York, Oxford University Press. 893 p.

Jayasingh D. B. \& C. A. Taffe. 1982. The biology of the eumenid mudwasp Pachodynerus nasidens in trapnests. Ecological Entomology 7: 283-289.

Krombein, K. V. 1967. Trap-nesting wasps and bees. Life histories, and associates. Washington, DC, Smithsonian Institute Press, $570 \mathrm{p}$.
Morato, E. F. \& R. P Martins. 2006. An overview of proximate factors affecting the nesting behavior of solitary wasps and bees (Hymenoptera: Aculeata) in preexisting cavities in wood. Neotropical Entomology 35: 285-298.

Molumby, A. 1995. Dynamics of parasitism in the organ-pipe wasp, Trypoxylon politum: effects of spatial scale on parasitoid functional response. Ecological Entomology 20: 159-168.

Molumby, A. 1997. Why make daughter larger? Maternal sex-allocation and sex-dependent selection for body size in a mass-provisioning wasp, Trypoxylon politum. Behavior Ecology 8: 279-287.

Oku, S. \& T. Nishida. 1999. Factors affecting female-biased Sex ratio in trap nesting wasp, Trypoxylon malaisei. Researches on Population Ecology 41: 169-175.

Peruquetti, R. C. \& M. A. Del Lama. 2003. Alocação sexual e seleção sexo-dependente para tamanho de corpo em Trypoxylon rogenhoferi Kohl (Hymenoptera, Sphecidae). Revista Brasileira de Entomologia 47: 581-588.

Potts, S. G. \& P. Willmer. 1997. Abiotic and biotic factors influencing nest-side selection by Halictus rubicundus, a ground nest halictine bee. Ecological Entomology 22: 319-328.

Richards, O. W. 1934. The American species of the genus Trypoxylon. Transactions of the Royal Entomological Society of London 82: 173-362.

Rosenheim J. A.; P. Nonacs \& M. Mangel, 1996. Sex ratios and multifaceted parental investment. American Naturalist 148: 501-535.

Roubik, D. W. 1989. Ecology and Natural History of Tropical Bees. Cambridge, Cambridge University Press, 514 p.

Storch D. \& D. Frynta 2000: Evolution of habitat selection: stochastic acquisition of cognitive clues? Evolutionary Ecology 13: 591600.

Zar, J. H. 1999. Biostatitical analysis (4th Ed.). New Jersey, Prentice Hall, $663 \mathrm{p}$.

Received 21/09/2006; accepted 12/06/2007 